\title{
EFFECT OF SODIUM ARSENITE ON THE KIDNEY AND ITS REMEDY WITH COMBINED EXTRACTS OF ALLIUM SATIVUM AND GONGRONEMA LATIFOLIUM USING RATS
}

\author{
Usoh, I. F. \\ Department of Biochemistry, \\ Faculty of Basic Medical Sciences, \\ University of Uyo, \\ Uyo, \\ Nigeria
}

\author{
Akwa, N. E." \\ Department of Biochemistry, \\ Faculty of Basic Medical Sciences, \\ University of Uyo, \\ Uyo, \\ Nigeria
}

Article DOI: https://doi.org/10.36713/epra3286

\begin{abstract}
Sodium arsenite is a toxicant with nephrotoxic potential. This study proves that combined extracts of Gongronema latifolium and Allium sativum can protect the kidney from this toxicity. Fifty male Wistar rats (115 - $280 \mathrm{~g}$ ) were obtained for this experiment. They were sustained with commercial rat's feed pellets and water. The rats were grouped into ten groups of five rats each. Group1 rats were the normal control, Groups 2, 3 and 4 were administered with $10 \mathrm{mg} / \mathrm{kg}$ bw of sodium arsenite intraperitoneally on day 1only, day 1 - 7 and day 7 only, respectively. Groups 5 and 6 rats were administered with $200 \mathrm{mg} / \mathrm{kg}$ bw of Gongronema latifolium and Allium sativum respectively through oral gavaging from day $1-6$, and $10 \mathrm{mg} / \mathrm{kg}$ bw of sodium arsenite intraperitoneally on day 7, respectively. Group 7 rats were administered with 100mg/kgbw each of Gongronema latifolium and Allium sativum through oral gavaging from day 1 - 6, and $10 \mathrm{mg} / \mathrm{kgbw}$ of sodium arsenite intraperitoneally on day 7. Groups 8 and 9 rats were administered with 200mg/kg bw of Gongronema latifolium only and Allium sativum only, respectively through oral gavaging. Group 10 rats were treated with 100mg/kg bw each of Gongronema latifolium and Allium sativum through oral gavaging from day 1 to 7 . The rats were sacrificed 24 hours after the last administration and blood sample was collected for kidney function tests, and also the kidney for histological analysis. The results showed that the rats treated with sodium arsenite only, for different durations, had different degrees of nephrotic damage while those treated with single extracts and the toxicant showed moderate damage. The group treated with combined extracts and the toxicant was completely protected from all forms of nephrotic damage as evidently observed.
\end{abstract}

KEYWORDS: Allium sativum; Gongronema latifolium; kidney; nephrotoxicity; rats; sodium arsenite.

\subsection{INTRODUCTION}

The kidney is an important organ which plays a major role in excretion and homeostasis [1], so therefore it is pertinent for it to be protected from damage. Sodium arsenite is a compound with a metalloid element (arsenite), which is considered to be a threat to life because of its toxicity level [2]. It damages the kidney by the alteration of its cellular morphology and functional activities [3].sodium arsenite can enter the body through inhalation, contact on the skin, ingestion through food and water [4]. On entry into the body, the kidney is usually one of the primary targeted organs. The proximal convulated tubule is usually affected. Sodium arsenite toxicity leads to increase in oxidative stress, therefore increasing the expressing of heme oxygenase-1 and Mitogen Activated Protein Kinase which by regulating various transcription factors such as Activator Protein-1(AP-1) and Activating Transcription Factor-2 (ATF-2) leads to renal toxicity [5] as shown in figure 1.1 


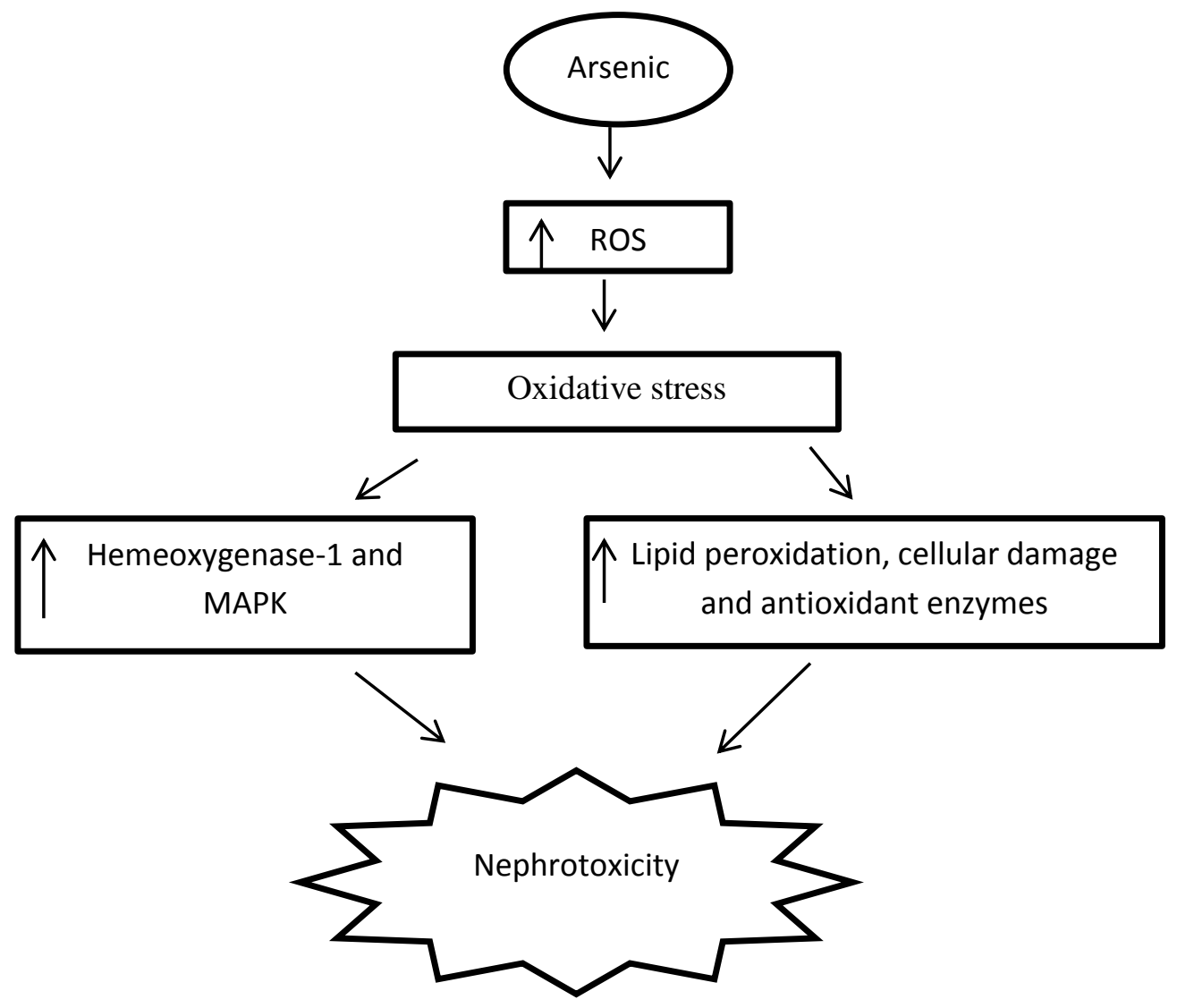

Figure 1.1: Pathological mechanisms involved in arsenic - induced nephrotoxicity Source: By the researcher

Researchers have been able to establish that most medicinal plants have broad spectrum therapeutic effects with minimal or no side effects [6]. Allium sativum (Garlic) and Gongronema latifolium have been found to be effective in the remedy of nephrotoxicity caused by sodium arsenite.

Allium sativum belong to the Amaryllidaceae family and classified into same genus as onion. It has been proven to be highly medicinal [7]. Glutamyl cysteins are the primary sulphur component forming the sulphur compounds that are present in Allium sativum which is responsible for its taste, smell and biological effects [8]. Allicin is a major active component of Allium sativum which is gotten when crushed by either chewing or chopping, therefore releasing alliin which reacts quickly with alliinase in thirty seconds to form the allicin [9]. Among the several protective properties of Allium sativum is its antioxidative effect. It has been shown to protect the kidney by reducing reactive oxygen species by enhancing antioxidative enzymes and reducing lipid peroxidation [10].

Gongronema latifolium is a widely known plant in Nigeria with a local name as "utazi" or "utasi". Most Nigerians used it to make sauce as delicacy. It has broad leaves and bitter taste. It possesses anticancer, antimicrobial, and anti- inflammatory properties, making it a very potent medicinal plant [11]. This medicinal plant has been proven to have kidney function potentials [12]

\subsection{MATERIALS AND METHODS}

All the chemicals, reagents used in this research were of analytical grades and the equipment were of international standard.

\subsubsection{Collection and Preparation of Plants Materials}

Allium sativum bulb and fresh leaves of Gongronema latifolium were purchased from Itam market, Uyo in Akwa-Ibom state. They were authenticated by the Botany Department of University of Uyo, Uyo. The Gongronema latifolium leaves were air dried for three days while the Allium sativum bulbs were cut to smaller pieces and air dried for five days at room temperature. One thousand gram each of the dried leaves of Gongronema latifolium and Allium sativum pieces, were blended separately with KENWOOD electric blender (KENWOOD LTD. ENGLAND), and soaked in $80 \%$ ethanol for 24 hours. There after it was sieved with a WhatMan No. 1 filter paper to remove the excess ethanol. The filtrates were separately concentrated in vacuo at $37-40{ }^{\circ} \mathrm{C}$ using a rotary evaporator. The concentrates were allowed open in a water bath at 40 
${ }^{\circ} \mathrm{C}$ for complete ethanol removal. The dried extracts were refrigerated at $2-8{ }^{\circ} \mathrm{C}$ until required for use. The concentrations of the extracts were determined by drying a volume and measuring the dried weight.

\subsubsection{Experimental Animals and Grouping}

Fifty male Wistar rats $(115-280 \mathrm{~g})$ were obtained, grouped into ten groups of five each and housed in well ventilated cages (wooden bottom and wire mesh top) and kept under controlled environmental conditions of temperature $\left(25 \pm 5^{\circ} \mathrm{C}\right)$, relative humidity $(50 \pm 5 \%)$ and twelve hour light/dark cycle in the animal house of University of
Uyo, Uyo. Akwa Ibom state. The animals were fed with commercial rat pellets obtained from Uyo and also allowed free access to water.

\subsubsection{Experimental Design}

Animals were randomized into ten groups of five each as in Table 2.1. The extracts and sodium arsenite, dissolved in distilled water were administered orally and intraperitoneally, respectively.

Table 2.1: Experimental Design

\begin{tabular}{|c|c|c|}
\hline Id & Group & Treatment \\
\hline NC & 1 & Only normal feed \\
\hline $\mathrm{SA}^{1}$ & 2 & $10 \mathrm{mg} / \mathrm{kg}$ body weight of sodium arsenite only on day 1 \\
\hline $\mathrm{SA}^{1-7}$ & 3 & $10 \mathrm{mg} / \mathrm{kg}$ body weight of sodium arsenite from day 1 to day 7 \\
\hline $\mathrm{SA}^{7}$ & 4 & $10 \mathrm{mg} / \mathrm{kg}$ body weight of sodium arsenite only on day 7 \\
\hline GLSA & 5 & $\begin{array}{l}200 \mathrm{mg} / \mathrm{kg} \text { bodyweight of Gongronema latifolium from day1 to } 6 \\
\text { and } 10 \mathrm{mg} / \mathrm{kg} \text { body weight of sodium arsenite on day } 7\end{array}$ \\
\hline ASSA & 6 & $\begin{array}{l}200 \mathrm{mg} / \mathrm{kg} \text { bodyweight of Allium sativum from day } 1 \text { to } 6 \text { and } \\
10 \mathrm{mg} / \mathrm{kg} \text { body weight of sodium arsenite on day } 7\end{array}$ \\
\hline GLASSA & 7 & $\begin{array}{l}100 \mathrm{mg} / \mathrm{kg} \text { body weight each of Allium sativum and Gongronema latifolium for } \\
6 \mathrm{days} \text { and } 10 \mathrm{mg} / \mathrm{kg} \text { body weight of sodium arsenite only on day } 7\end{array}$ \\
\hline GL & 8 & $200 \mathrm{mg} / \mathrm{kg}$ body weight of Gongronema latifolium from day 1 - 7 \\
\hline AS & 9 & $200 \mathrm{mg} / \mathrm{kg}$ body weight of Allium sativum from day $1-7$ \\
\hline GLAS & 10 & $\begin{array}{l}100 \mathrm{mg} / \mathrm{kg} \text { body weight each of Allium sativum and Gongronema latifolium for } \\
7 \text { days }\end{array}$ \\
\hline
\end{tabular}

NC: Normal control, SA: Sodium arsenite, GLSA: Gongronema latifolium and sodium arsenite, ASSA: Allium sativum and sodium arsenite, GLASSA: Gongronema latifolium, Allium sativum and sodium arsenite, GL: Gongronema latifolium, AS: Allium sativum, GLAS: Gongronema latifolium and Allium stadium

\subsubsection{Collection of Samples for Analysis}

The animals were sacrificed $24 \mathrm{hrs}$ after the last administration, by euthanizing them under chloroform vapour and sacrificed, then whole blood was collected via cardiac puncture using sterile syringes and needles and put in plain container. Serum was separated by centrifugation $(3000 \mathrm{rpm}$ at $4^{\circ} \mathrm{C}$ for $5 \mathrm{mins}$ ) in a centrifuge machine (model 800-1, Zeny Inc. Salt Lake, USA). The kidney was harvested and rinsed in normal saline, and was preserved in $10 \%$ formalin for histological analysis.

\subsubsection{Determination of Kidney Function Test \\ Rat Serum Urea Concentration (Diacetyl monoxime Colorimetric Method)}

Urea reacts directly with diacetyl monoxime under strong acidic conditions to give a yellow condensation product. The reaction is intensified by the presence of ferric ions and thiosemicarbazide. The intense red colour formed is measured at $540 \mathrm{~nm}$ [13].

Rat Serum Creatinine Estimation Assay (Jaffe's Reaction Method)

Alkali Creatinine + Sodium Picrate $\rightarrow$ Creatinine Picrate complex (yellow-orange) 
Creatinine reacts with picric acid in alkaline conditions to form a colour complex, which absorbs at $510 \mathrm{~nm}[14]$.

\section{Rat Potasium Estimation Assay (Colorimetric method)}

This is a colorimetric method where the amount of potassium was determined by using sodium tetraphenylboron in a specifically prepared mixture to produce a colloidal suspension. The turbidity of which is proportional to potassium concentration [15].

\section{Rat Sodium Estimation Assay (Colorimetric Method)}

This method is based on modifications in which sodium is precipitated as the triple salt, sodium magnesium uranyl acetate, with the excess uranium then being reacted with ferrocyanide, producing a chromophore whose absorbance varies inversely as the concentration of sodium in the test specimen [15].

\section{Rat Chloride Estimation Assay (Colorimetric method) \\ $\mathrm{Hg}(\mathrm{SCN})_{2}+2 \mathrm{CI}^{-} \rightarrow \mathrm{HgCI}_{2}+2 \mathrm{SCN}^{-}$ Equation 2.1 $3 \mathrm{SCN}^{-}+\mathrm{Fe}_{3}^{+} \rightarrow 4 \mathrm{Fe}(\mathrm{SCN})_{3}$} Equation 2.2

red complex chloride ions form a soluble, nonionized compound, with mercuric ions and will displace thiocyanate ions from non-ionized mercuric thiocyanate. The released thiocyanate ions react with ferric ions to form a colour complex that absorbs light at $480 \mathrm{~nm}$. The intensity of the colour produced is directly proportional to the chloride concentration [15].

\section{Rat Serum Bicarbonates Assay (Colorimetric method)}

Phosphoenol Pyruvate $+\mathrm{HCO}_{3}-$ PEPC $>$ Oxalate + $\mathrm{H}_{2} \mathrm{PO}_{4} \quad$ Equation 2.3

Oxalate + NADH $\mathrm{MDH}>$ Malate + NAD Equation 2.4

Phosphoenol pyruvate carboxylase (PEPC) catalyzes the reaction between phosphoenol pyruvate and carbon dioxide (bicarbonate) to form oxalacetate and phosphate ion. Oxalacetate is reduced to malate with simultaneous oxidation of an equimolar amount of reduced nicotinamide adenine dinucleotide (NADH) to NAD; the reaction is catalyzed by malate dehydrogenase (MDH). This results in a decrease in absorbance at $340 \mathrm{~nm}$ that is directly proportional to $\mathrm{CO}_{2}$ concentration in the sample [16].

\section{Histological Analysis}

The kidneys were carefully dissected out, trimmed of all fat and blotted dry to remove any blood. They were weighed and volume determined by water displacement and then fixed in $10 \%$ formal saline (fixation). The fixed tissues were transferred to a graded series of ethanol (dehydration). On day 1, they were placed in $70 \%$ alcohol for 7 hours, then transferred to $90 \%$ alcohol and left in the latter overnight. On day 2, the tissues were passed through three changes of absolute alcohol for an hour each, and then cleared in xylene (clearing). Once cleared, the tissues were infiltrated in molten paraffin wax in the oven at $58^{\circ} \mathrm{C}$. Three changes of molten paraffin wax (impregnation) at one-hour intervals were made, after which the tissues were embedded (embedding) in wax and blocked out. Prior to embedding, it was ensured that the mounted sections to be cut by the rotary microtome were oriented perpendicularly to the long axis of the tissues. The sections were designated "vertical sections". Serial sections of $5 \mu \mathrm{m}$ thick were obtained from a solid block of tissue (microtomy) fixed on clean albuminized slides to prevent sections from pulling off the slides and later stained with haematoxylin and eosin staining techniques, after which they were passed through grades of alcohol, cleared in xylene and mounted in DPX (Distyrene - Plasticizer and xylene) mountant and observed under digital light microscope [17].

\subsubsection{Statistical analysis}

All values were expressed as mean \pm standard deviation (SD) of five animals in a group. The test of significance between two groups was estimated by student's t-test with P-values $<0.05$ considered statistically significant. 
EPRA International Journal of Multidisciplinary Research (IJMR) - Peer Reviewed Journal

Volume: 6 | Issue: 8 | August 2020 || Journal DOI: 10.36713/epra2013 || SJIF Impact Factor: 7.032 ||ISI Value: 1.188

\section{Results and Discussion}

Table 3.1: Effect of combined extracts of Allium sativum and Gongronema latifolium on kidney function of sodium arsenite induced toxicity in rats

\begin{tabular}{|c|c|c|c|c|c|c|c|}
\hline Group & 1d & $\begin{array}{l}\text { Creatinine } \\
\text { (Mg/dl) }\end{array}$ & Urea $(\mathrm{Mg} / \mathrm{dl})$ & $\begin{array}{l}\text { Bicarbonate } \\
\text { (Mmol/L) }\end{array}$ & $\begin{array}{l}\text { Sodium } \\
\text { (Mmol/L) }\end{array}$ & Potassium (Mmol/L) & Chloride (Mmol/L) \\
\hline 1 & NC & $0.312 \pm 0.065^{\mathrm{abc}}$ & $17.22 \pm 3.382^{\mathrm{abc}}$ & $27.6 \pm 2.302^{\mathrm{abc}}$ & $143.6 \pm 4.037^{\mathrm{ab}}$ & $3.71 \pm 0.352^{\mathrm{abcd}}$ & $99.8 \pm 6.943^{\mathrm{abc}}$ \\
\hline 2 & $\mathrm{SA}^{1}$ & $0.598 \pm 0.234^{* a b d}$ & $26.14 \pm 2.397 * \mathrm{abd}$ & $36.0 \pm 2.739 * a d$ & $149.2 \pm 4.658^{\mathrm{a}}$ & $6.40 \pm 0.345^{* \mathrm{bd}}$ & $109 \pm 4.301^{* a b d}$ \\
\hline 3 & $\mathrm{SA}^{1-7}$ & $0.99 \pm 0.056^{* \mathrm{bcd}}$ & $41.97 \pm 6.536^{* \mathrm{bcd}}$ & $44.5 \pm 7.674^{* \mathrm{bcd}}$ & $162 \pm 3.606^{* \mathrm{bcd}}$ & $7.29 \pm 1.286^{* b d}$ & $154.7 \pm 28.43^{* b c d}$ \\
\hline 4 & $\mathrm{SA}^{7}$ & $0.718 \pm 0.069 *$ acd & $33.03 \pm 3.043^{*} \mathrm{acd}$ & $37.0 \pm 3.769^{* a d}$ & $155.75 \pm 8.77^{* d}$ & $6.57 \pm 0.508^{* d}$ & $114 \pm 6.633^{* a d}$ \\
\hline 5 & GLSA & $0.65 \pm 0.0496^{* a d}$ & $24.75 \pm 1.068^{* a b d}$ & $34.0 \pm 2.160^{* a d}$ & $149.3 \pm 6.994^{\mathrm{a}}$ & $5.21 \pm 0.376^{* \mathrm{bd}}$ & $100.75 \pm 5.439$ abcd \\
\hline 6 & ASSA & $0.51 \pm 0.113^{* a b d}$ & $21.82 \pm 1.769^{*} \mathrm{abd}$ & $30.8 \pm 2.588^{\mathrm{abc}}$ & $141.6 \pm 3.646^{a b}$ & $4.514 \pm 0.404^{* a b c}$ & $91.4 \pm 11.41^{\mathrm{abc}}$ \\
\hline 7 & GLASSA & $0.33 \pm 0.054^{\mathrm{abc}}$ & $14.28 \pm 1.18^{\mathrm{abc}}$ & $26.7 \pm 2.533^{\mathrm{abc}}$ & $146.3 \pm 8.180^{\mathrm{b}}$ & $4.22 \pm 0.692^{\mathrm{abc}}$ & $86.75 \pm 10.9^{a b c}$ \\
\hline 8 & GL & $0.575 \pm 0.09^{* a b d}$ & $24.85 \pm 1.64^{* a b d}$ & $34.0 \pm 1.825^{* a d}$ & $146.5 \pm 5.066^{b}$ & $5.088 \pm 0.177^{* a b c}$ & $100.25 \pm 3.59 \mathrm{abcd}$ \\
\hline 9 & AS & $0.304 \pm 0.04^{\mathrm{abc}}$ & $15.24 \pm 2.057 \mathrm{abc}$ & $26.4 \pm 3.209 \mathrm{abc}$ & $139.4 \pm 1.341^{\mathrm{abc}}$ & $4.0 \pm 0.2246^{\mathrm{abc}}$ & $97.4 \pm 10.45^{\mathrm{abcd}}$ \\
\hline 10 & GLAS & $\begin{array}{l}0.228 \pm \\
0.032 * \text { abcd }\end{array}$ & $11.56 \pm 5.85^{* a b c}$ & $25.820 \pm 1.54^{\mathrm{abc}}$ & $141.4 \pm 9.48^{\mathrm{ab}}$ & $4.192 \pm 0.48^{a b c}$ & $99.4 \pm 4.97 \mathrm{abcd}$ \\
\hline
\end{tabular}

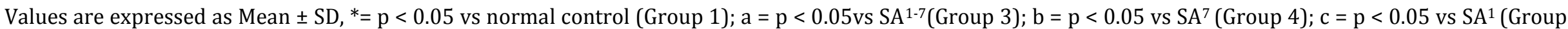
2), $\mathrm{d}=\mathrm{p}<0.05 \mathrm{vs}$ GLASSA (Group 7)

Source: Field data 
Table 3.1 showed that urea and creatinine levels were significantly $(\mathrm{p}<0.05)$ higher in all the groups treated with sodium arsenite exception of Group 7 animals, while a significant reduction was observed in Group 10 animals when compared to the control group (Group 1). The group with the longest duration of exposure to sodium arsenite only (Group 3) had significantly raised urea and creatinine levels when compared to all other groups.
The table also showed that the electrolytes levels were significantly raised in all the groups treated with sodium arsenite only, except in Group 2 when compared to the control group (Group 1).

The electrolytes levels were same with control group in all the extract treated groups exception of significant increase in potassium level of Groups 5, 6, and 8 . Bicarbonate level was also significantly raised in Groups 5 and 8 only.

\section{Histopathology of the kidney}

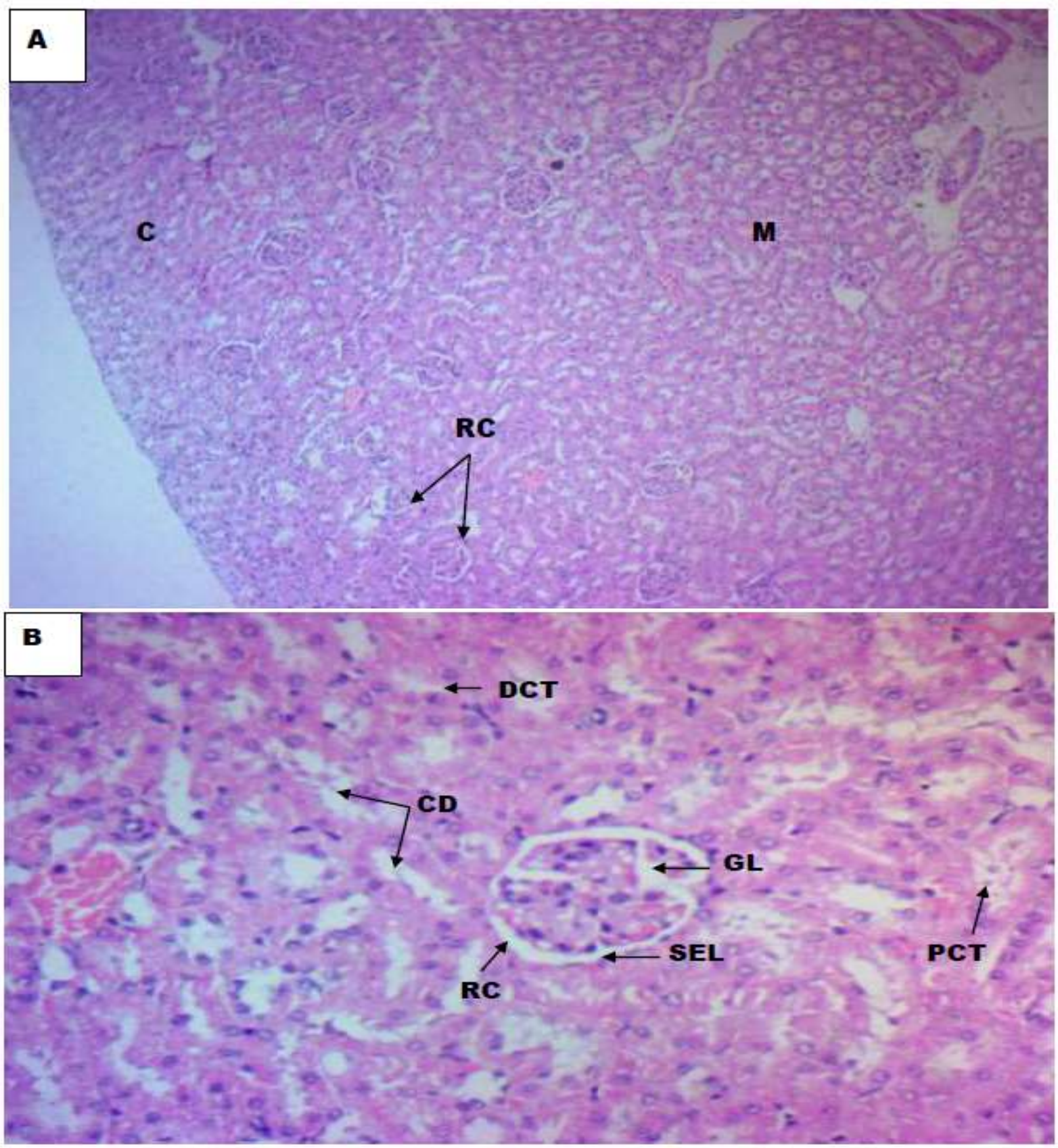

Figure 3.1:

Photomicrographs of control kidney (Group 1) without treatment stained with H and E method at Mag. A (X100) and B (X400). Keys: Renal corpuscle (RC), Cortex (C), Medulla (M), Squamous Epithelial Lining (SEL), Proximal Convulated Tubules (PCT), Distal Convoluted Tubules (DCT) and Collecting Duct CD), Glomerulus (GL) 

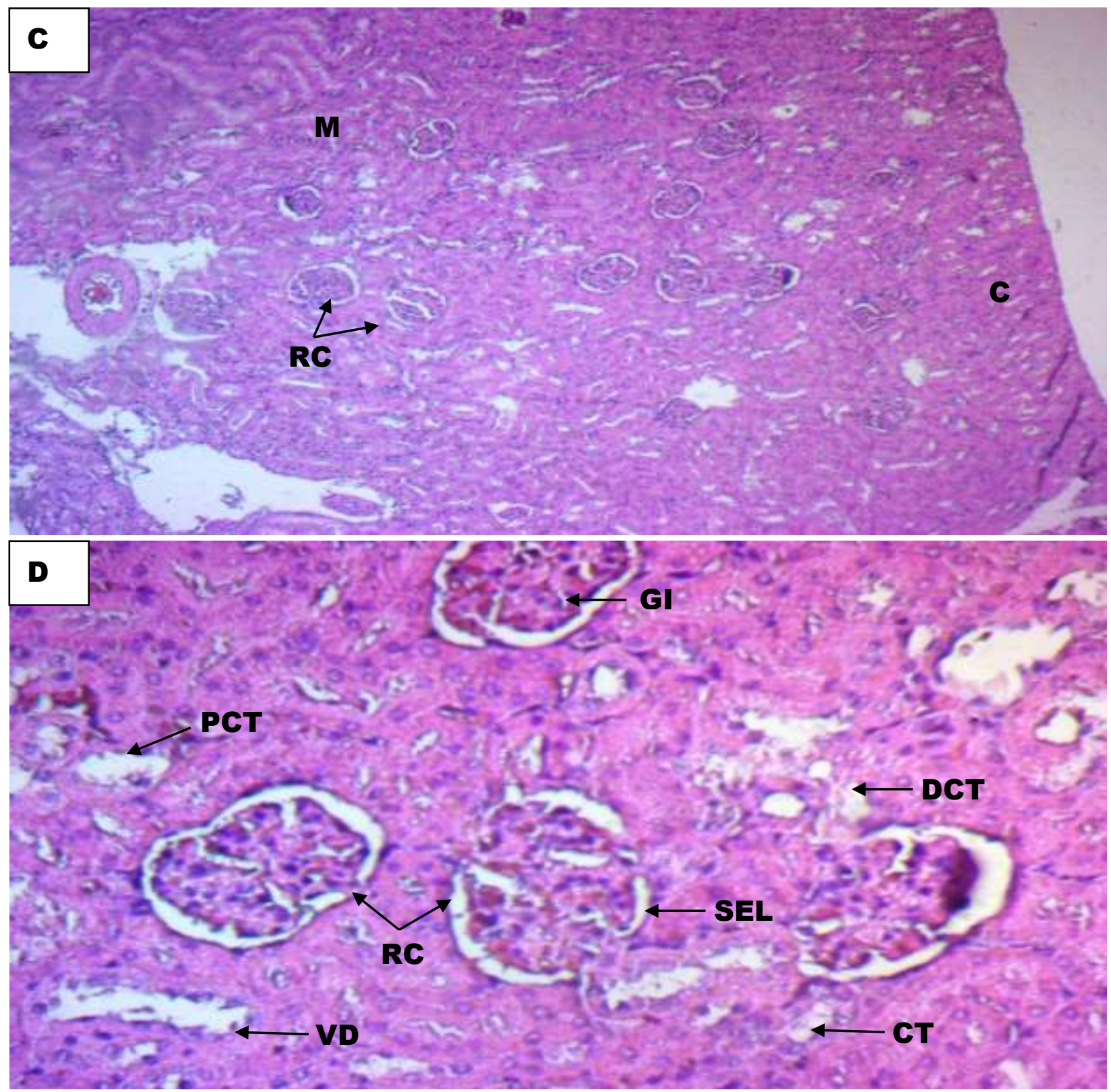

Figure 3.2: $\quad$ Photomicrographs of Kidney of Group 2 rats, stained with H and E method at Mag.C (X100) and D (X400).

Keys: Renal corpuscle (RC), Cortex (C), Medulla (M), Squamous Epithelial Lining (SEL), Proximal Convulated Tubules (PCT), Distal Convulated Tubules (DCT) and Vascular degenration (VD), Glomerular Iinflamation (GI) and Pyknotic nucleus (Pn) Source: Field data 


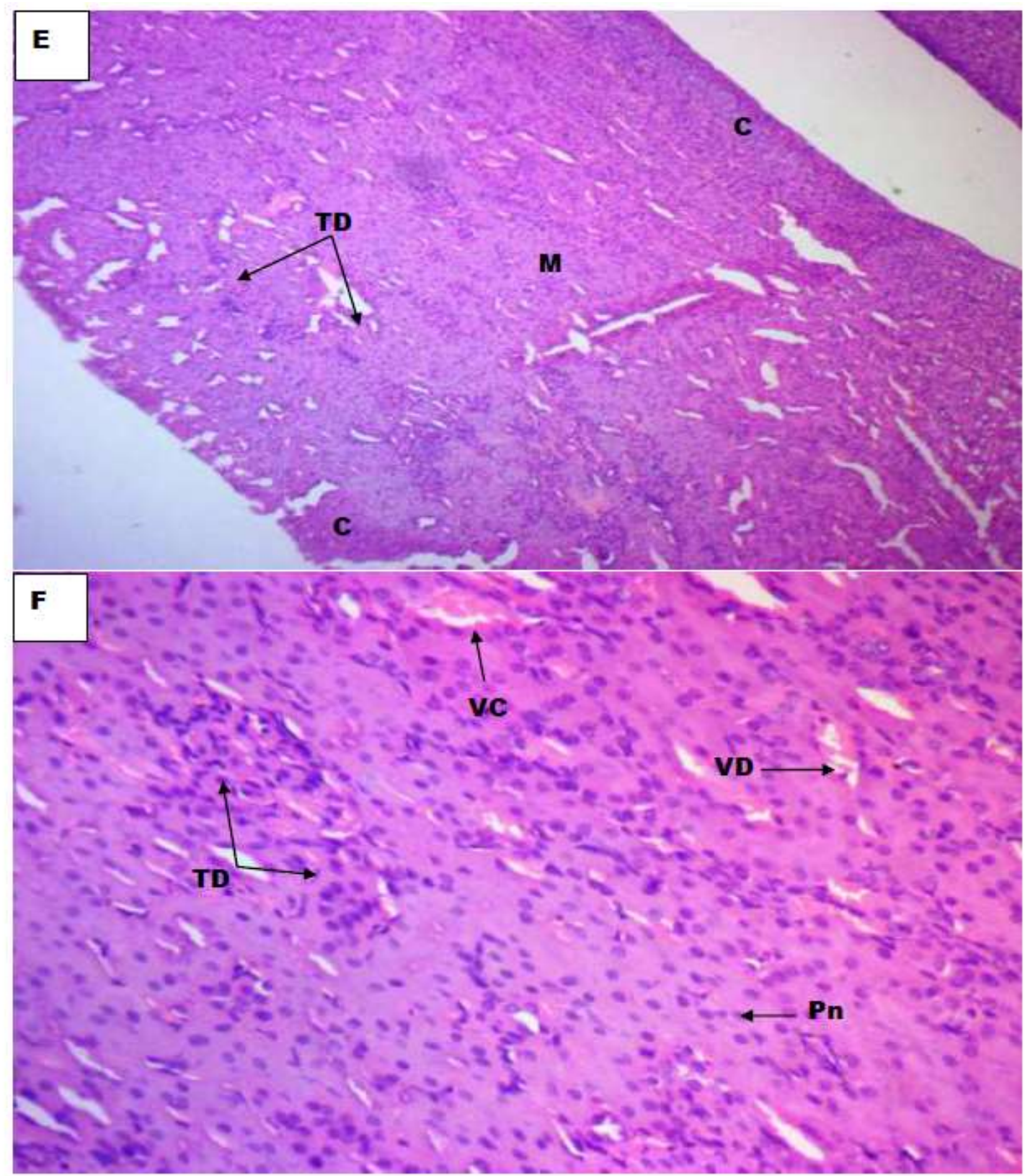

Figure 3.3: Photomicrographs of Kidney of Group 3 rats, stained with H and E method at Mag. E (X100) andF (X400).

Keys:Tubular Degeneration (TD), Cortex (C), Medulla (M), Vascular congestion (VC), Vascular degeneration (VD) and Pyknotic nucleus (Pn)

Source: Field data 


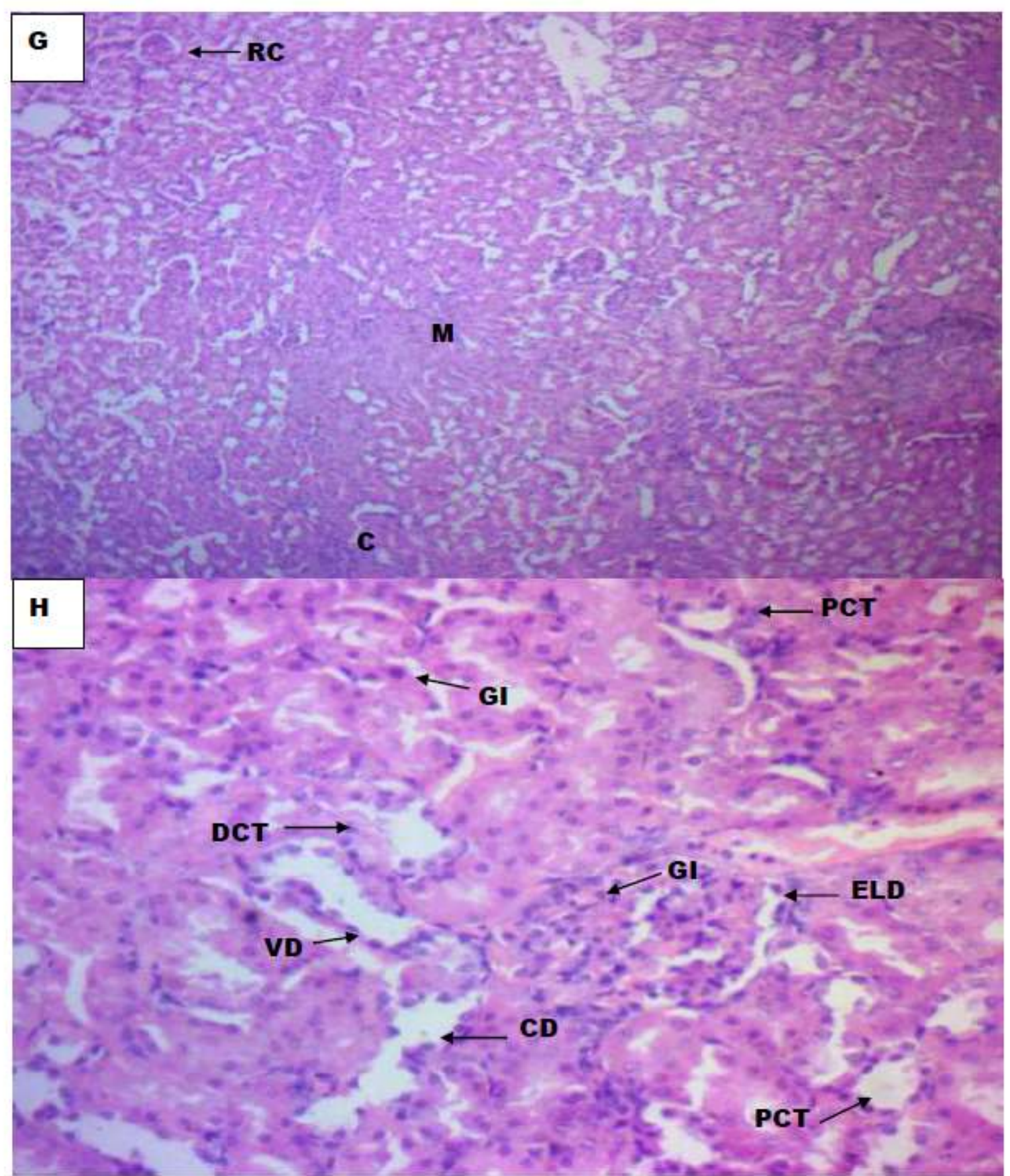

Figure 3.4: Photomicrographs of Kidney of Group 4 rats, stained with H and E method at Mag. G (X100) and $\mathrm{H}(\mathrm{X} 400)$.

Keys: Renal corpuscle (RC), Cortex (C), Medulla (M), Epithelial lining degeneration (ELD), Proximal Convulated Tubules (PCT), Distal Convulated Tubules (DCT) and Vascular degeneration (VD), Glomerular Inflamation (GI) and Pyknotic nucleus (Pn)

Source: Field data 


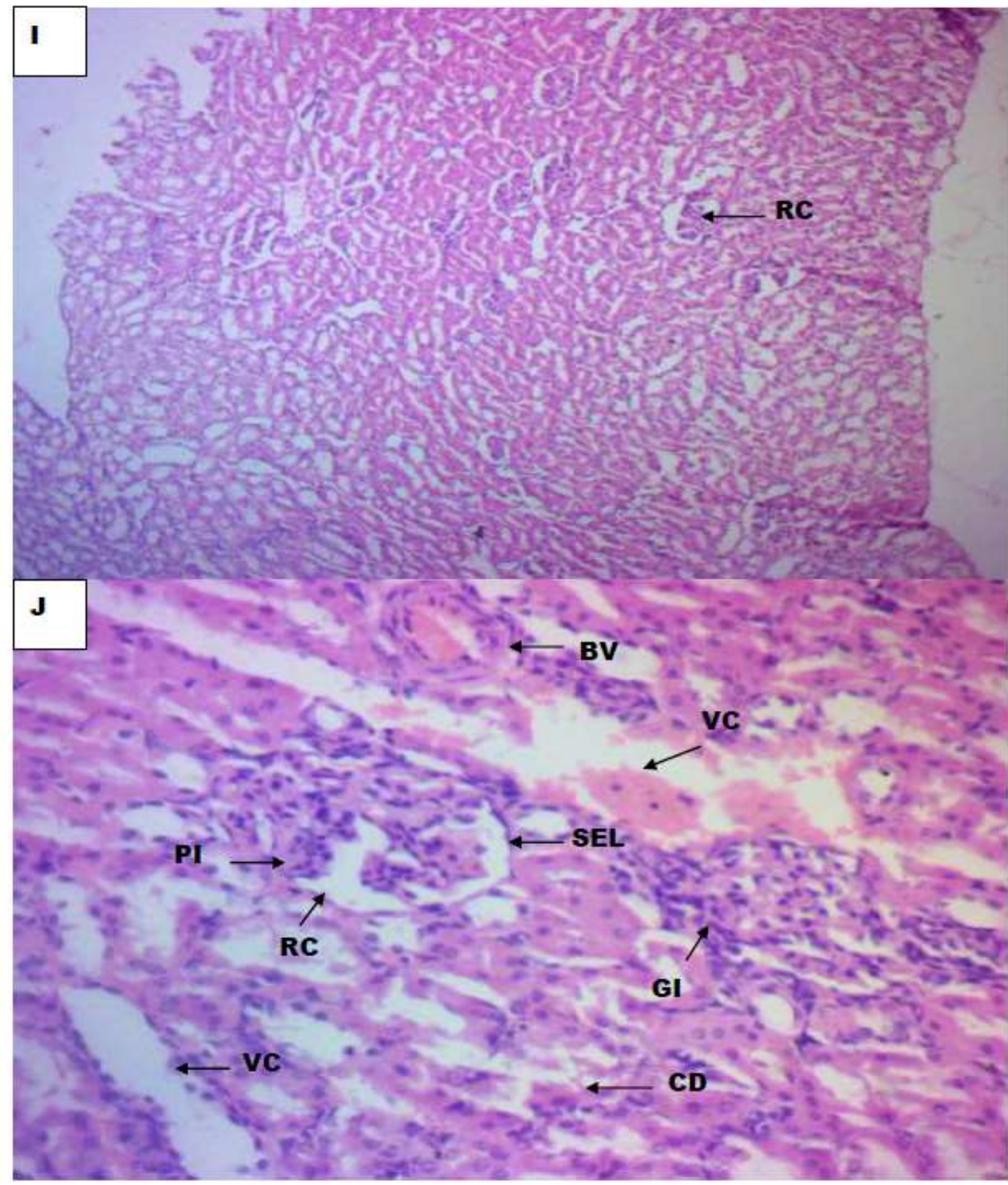

Figure 3.5: $\quad$ Photomicrographs of Kidney of Group 5 rats, stained with H and E method at Mag. I (X100) and $\mathrm{J}(\mathrm{X} 400)$.

Keys: Renal corpuscle (RC), Squamous Epithelial lining (SEL), Proximal Convulated Tubules (PCT), Distal Convulated Tubules (DCT), Collecting ducts (CD) and Glomerular Inflammation (GI), Blood vessel (BV) and Peritubular Inflammation (PI)

Source: Field data 


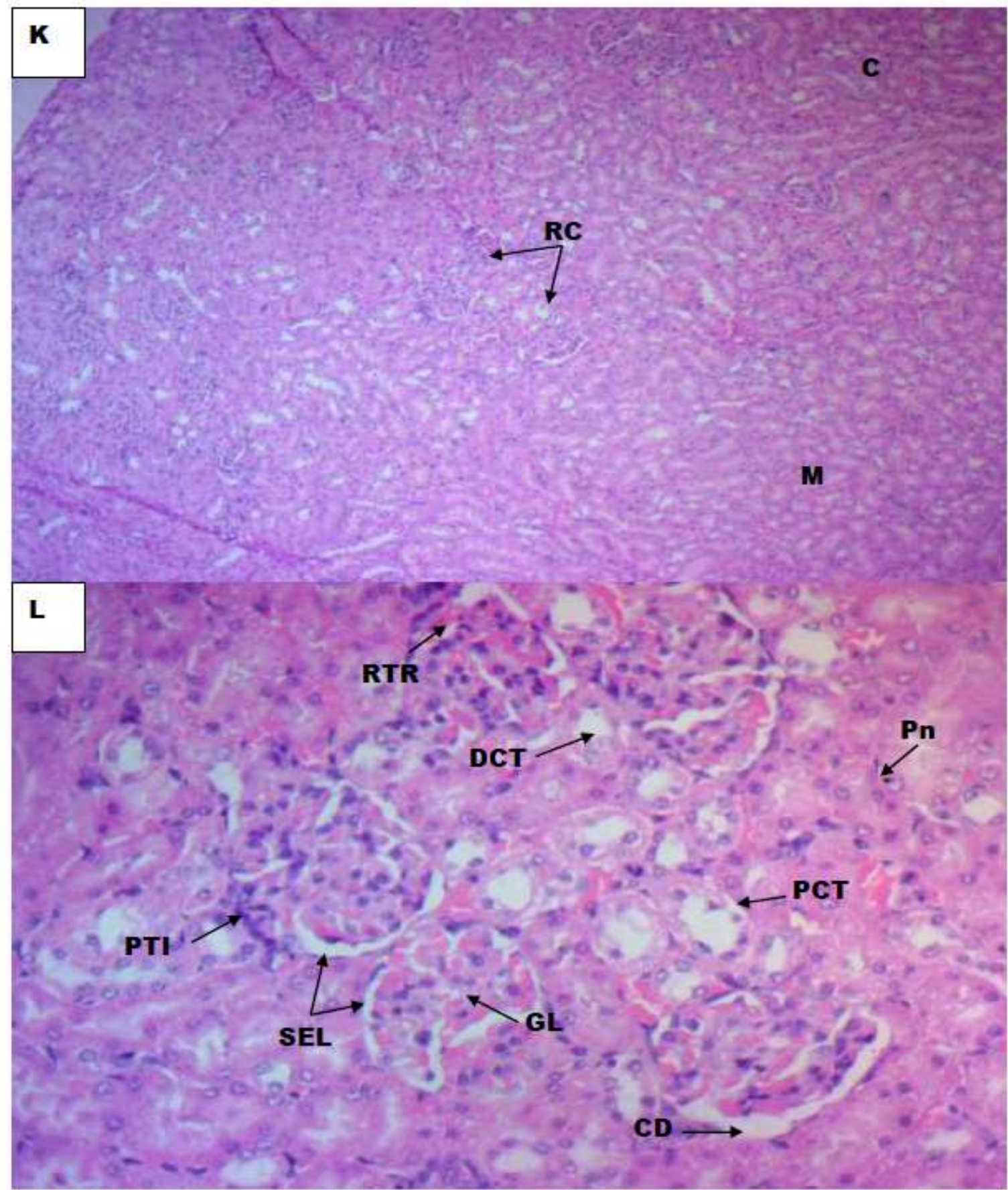

Figure 3.6: $\quad$ Photomicrographs of Kidney of Group 6 rats, stained with H and E method at Mag. K (X100) and $\mathrm{L}(\mathrm{X} 400)$.

Keys: Renal corpuscle (RC), Cortex (C), Medulla (M), Squamous Epithelial lining degeneration (SEL), Proximal Convulated Tubules (PCT), Distal Convulated Tubules (DCT) and Collecting ducts (CD), Renal Tubular Restoration (RTR) and Peritubular Inflammation (PTI)

Source: Field data 


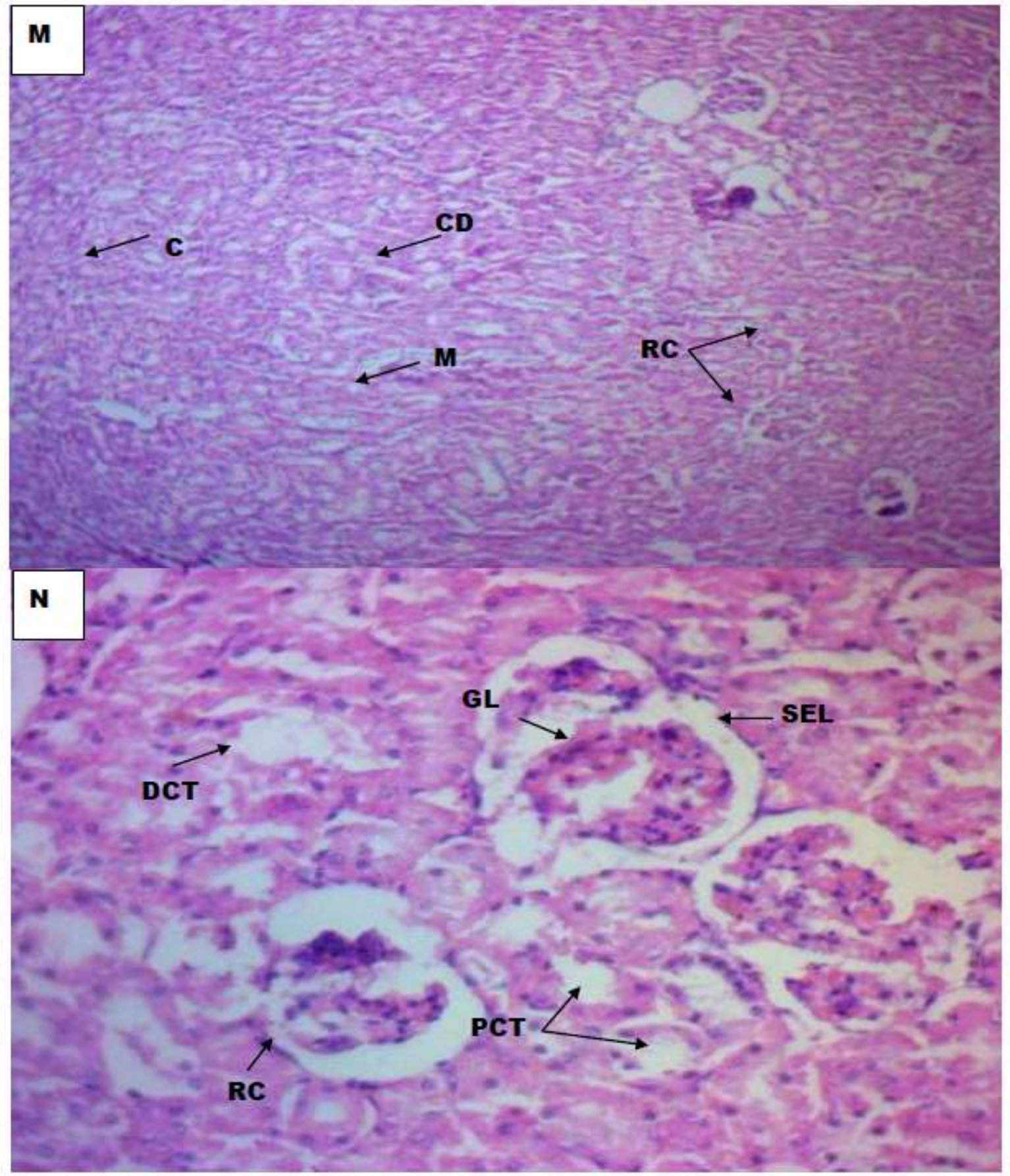

Figure 3.7: $\quad$ Photomicrographs of Kidney of Group 7, stained with H and E method at Mag. M (X100) and $\mathrm{N}(\mathrm{X} 400)$.

Keys: Renal corpuscle (RC), Cortex (C), Medulla (M), Squamous Epithelial lining (SEL), Proximal Convulated Tubules (PCT), Distal Convulated Tubules (DCT) Collecting ducts (CD) and Glomerulus (GL).

Source: Field data 


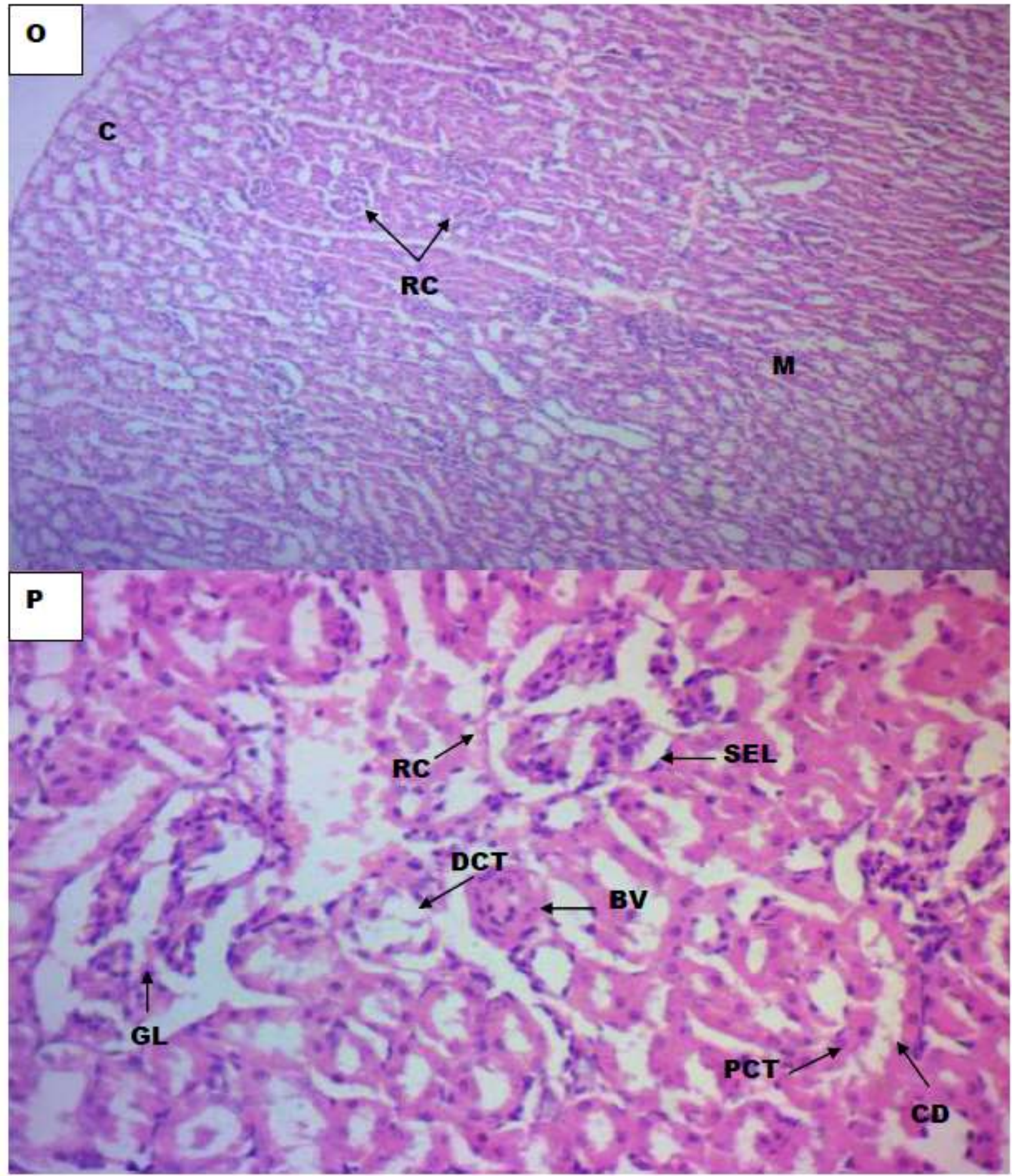

Figure 3.8:

Photomicrographs of kidney of Group 8 rats, stained with $\mathrm{H}$ and E method at Mag. O (X100) and $\mathrm{P}(\mathrm{X} 400)$.

Keys: Renal corpuscle (RC), Cortex (C), Medulla (M), Squamous Epithelial lining (SEL), Proximal Convulated Tubules (PCT), Distal Convulated Tubules (DCT) Collecting ducts (CD) Blood vessel (BV) and Glomerulus (GL).

Source: Field data 


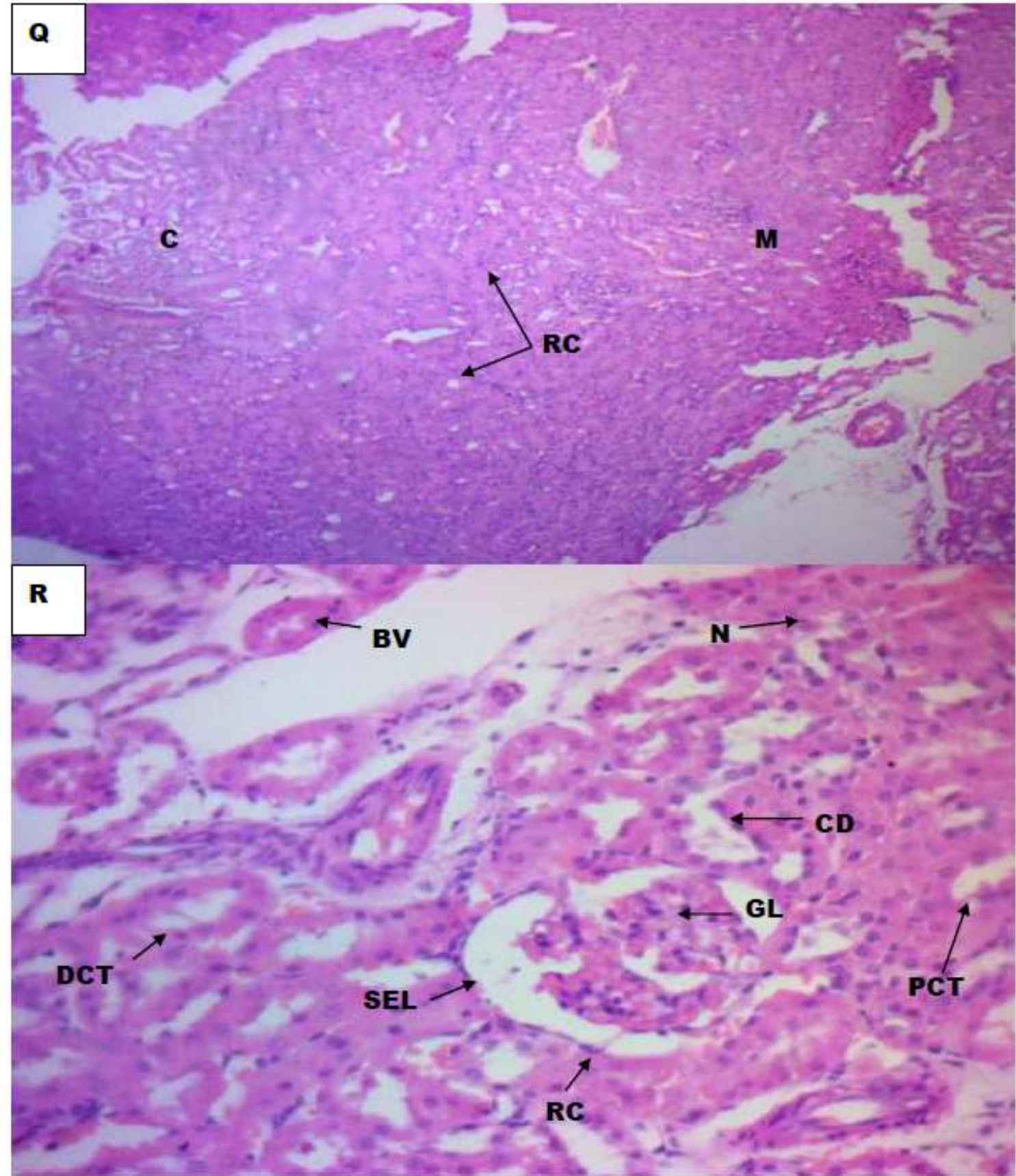

Figure 3.9: Photomicrographs of kidney of Group 9 rats, stained with $\mathrm{H}$ and $\mathrm{E}$ method at Mag. Q (X100) and $\mathrm{R}$ (X400).

Keys: Renal corpuscle (RC), Cortex (C), Medulla (M), Squamous Epithelial lining (SEL), Proximal Convulated Tubules (PCT), Distal Convulated Tubules (DCT), Collecting ducts (CD) and Glomerulus (GL).

Source: Field data 


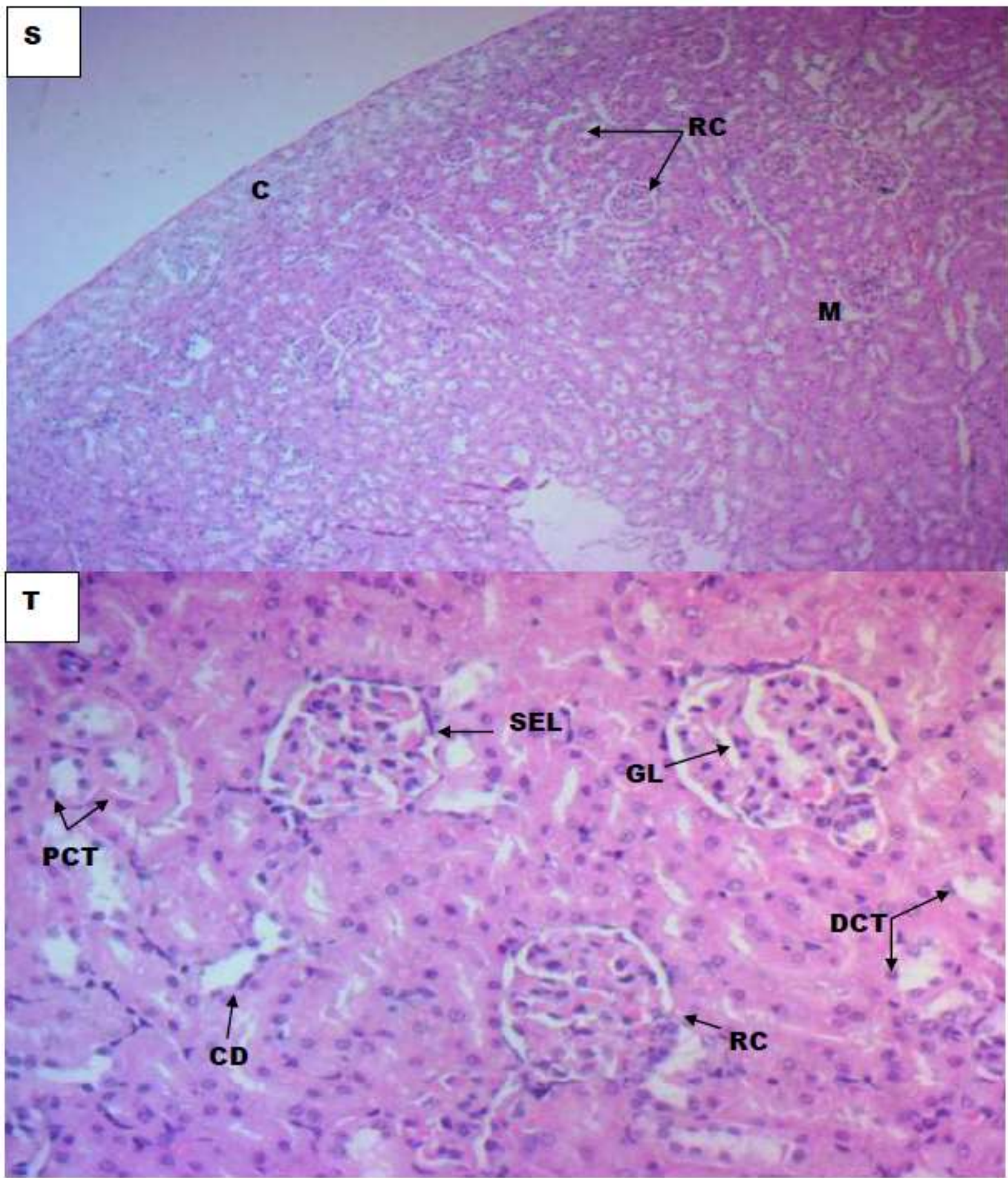

Figure 3.10: $\quad$ Photomicrographs of kidney of Group 10 rats, stained with H and E method at Mag. S (X100) and $\mathrm{T}(\mathrm{X} 400)$.

Keys: Renal corpuscle (RC), Cortex (C), Medulla (M), Squamous Epithelial lining (SEL), Proximal Convulated Tubules (PCT), Distal Convulated Tubules (DCT) Collecting ducts (CD) and Glomerulus (GL).

Source: Field data 
Figure $3.1-3.10$ presents the histological sections of the kidney of the rats in various groups.

Figure 3.1 represents Group 1(control group) rats without treatment at magnification $\mathrm{A}(\mathrm{x} 100)$ and $\mathrm{B}(\mathrm{x} 400)$ which revealed normal cellular profile of renal corpuscle containing distinct glomerulus, and lined with squamous epithelium within the cortex layer, the medulla region constitute the central area with numerous distal and proximal convulated tubules with well - defined collecting ducts all within normal cellular architecture without any form of abnormality.

Figure 3.2 showed histologic sections of the kidney of Group 2 rats at magnification C (x100) and D (x400) which revealed onset of glomerular inflammation without cellular abnormality when compared to control group. It was slightly affected.

Figure 3.3 showed histologic sections of the kidney of Group 3 rats at magnification E (x100) and $\mathrm{F}(\mathrm{x} 400)$ which revealed chronic tubular degeneration, vascular congestion, vascular degeneration against the background of numerous pyknotic nuclei when compared to control group. It was severely affected.

Figure 3.4 showed histologic sections of the kidney of Group 4 rats at magnification G (x100) and $\mathrm{H} \quad(\mathrm{x} 400)$ which revealed epithelial lining degeneration, glomerular inflammation against the background of numerous pyknotic nuclei when compared to control group. It was moderately affected.

Figure 3.5 showed histologic sections of the kidney of Group 5rats at magnification I (x100) and J (x400) which revealed glomerular and peritubular inflammation with slight changes in the cellular profile when compared to control group. It was slightly affected.

Figure 3.6 showed the histologic sections of the kidney of Group 6 rats at magnification of K (x100) and $\mathrm{L}(\mathrm{x} 400)$ which revealed active reversible effect with renal tubular restoration, though there was a strong evidence of peritubular inflammation when compared to control group. It was slightly affected.

Figure 3.7 showed the histologic sections of the kidney of Group 7 rats at magnification M (x100) and $\mathrm{N}(\mathrm{x} 400)$ which revealed complete restorative effect characterized with renal normal profile without any form of cellular abnormality when compared to control group. It was not affected.

Figure 3.8 showed the histologic sections of the kidney of Group 8 rats at magnification O (X100) and P (X400) which revealed cellular profile without any form of abnormality when compared to control group. It was not affected.

Figure 3.9 showed the histologic sections of the kidney of Group 9 rats at magnification Q (x100) and $\mathrm{R}$ (x400) which revealed well preserved cellular profile without any form of abnormality when compared to control group. It was not affected.

Figure 3.10 showed the histologic sections of the kidney of Group 10 rats at magnification S (x100) and $T(x 400)$ which revealed well preserved cellular profile without any form of abnormality when compared to control group. It was not affected.

The kidney is a functional organ for excretion alongside many other functions. A normal kidney functions in formation, acidification, concentration and or dilution of urine, along with filtration of blood at glomeruli and selective reabsorption of essential substances. Controlled reabsorption of salts and water, and secretion of certain substances depend upon an adequate flow of blood to the kidneys. Any situation interfering with this renal blood supply results in kidney dysfunction which alters the amount and composition of urine which result in the accumulation of metabolic waste product in blood [18]. During excretion of sodium arsenite, the proximal convulated tubule is usually affected. There is occurrence of renal toxicity leading to tubular necrosis, cast formation and increased blood urea nitrogen and creatinine levels [5, 19]. The kidney function tests (urea, creatinine and electrolytes) usually give valuable information about the status of the kidney function and frequently about the location of the defect. These defects and dysfunctions can also be confirmed by histological analysis of the kidneys [20].

This study showed that the animals that were treated with different duration of exposure to sodium arsenite only, suffered different degrees of kidney damage, with the one having the longest duration of exposure being severely affected as evident in their histological sections and in the significant rise in urea, creatinine and electrolyte levels, as well when compared to the control group. This proves that sodium arsenite has nephrotoxicity potential in which its severity depends on duration of exposure [21].

It was also observed from this study that although Group 2 and 4 animals had the same duration of exposure, Group 2 animals had lesser level of kidney damage compared to Group 4 animals as evident in their urea and creatinine levels significant difference as well as their kidney histology. This indicates that the kidney can recover to some extent after acute kidney injury [22].

The combined extracts and sodium arsenite treated group (Group7) was seen to confer a complete protective potential on the kidney compared to the Allium sativum and sodium arsenite treated group (Group 6) and the Gongronema latifolium and sodium arsenite treated group (Group 5). This was evident on the well preserved cellular profile without any form of abnormality of the histology section when compared to control group as well as the urea, creatinine and electrolyte levels being same with the control group.

In the groups treated with only extracts, it was observed that Group 8 (Gongronema latifolium only) had significant increase in urea, creatinine, bicarbonate and potassium levels whereas the histological sections indicated no damage. This finding is in line with researched by Nwangwu et al., 
(2011), in which Gongronema latifolium was observed to increase the level of some kidney function parameters [23].

\subsection{CONCLUSION}

This study confirms that sodium arsenite has toxic effect on the kidney and this toxicity can be prevented by the use of combined extracts of Gongronema latifolium and Allium sativum.

\section{Acknowledgments}

This research was not supported by any organisation or funding body. However, the authors contributed collectively to carry out the research.

\section{REFERENCES}

1. Bello - Reuss, E. and Reuss, L. (1983). Homeostatic and excretory functions of the kidney, pp 35 - 63 In: Klahr, S. (Editor). The kidney and body fluids in health and disease. Springer, Boston, MA, 593p.

2. Hughes, M. (2002). Arsenic toxicity and potential mechanism of action. Toxicology Letters, 133 (1): 1-16.

3. Nandi, D., Patra, D. and Swarup, D. (2005). Effect of cysteine, methionine, ascorbic acid and thiamine on arsenic induced oxidative stress and biochemical alterations in rats. Toxicology, 211:26 -35.

4. Singh, A., Goel, R. and Kaur, T. (2011). Mechanism pertaining to arsenite toxicity. International Journal of Toxicology, 211: 26-35.

5. Kimura, A., Ishida, Y., Hayashi, T., Wada, T., Yakoyama, H.and Sugaya, T. (2006). Interferongamma plays protective roles in sodium arseniteinduced renal injury by up regulating intra renal multidrug resistance- associated protein 1 expression. American Journal of Pathology, 169:1118-1128.

6. Alam, K., Hoq, M. and Uddin, S. (2016). Medicinal plant. Allium sativum $=a$ review. Journal of Medicinal Plant Studies, 4 (6): 72 -79.

7. Milner, J. (1996). Garlic: Its anticarcinogenic and antitumour properties. Nutrition Review, 54: $S 82$ $-86$.

8. Powolny, A. and Singh, S. (2008). Multitargeted prevention and therapy of cancer by diallyl trisulfide and related Allium vegetable - derived organosulfur compounds. Cancer Letters, 229: $305-314$.

9. Harunobu, A., Peteseh, B., Matsuura, H., Kasuga, S. and Itakura, Y. (2001). Intake of garlic and its bioactive component. Journal of Nutrition, 131: 955S-962S.

10. Borek, C. (2001). Antioxidant health effects of aged garlic extract. Journal of Nutrition, 131 (3s): $1010 \mathrm{~s}-1015 \mathrm{~s}$

11. Usoh, I. F., Akwa, N. E., Oyebadejo, S. A. and Ekpo, N. D. (2009). Protective potential of Gongronema latifolium and Allium sativum extracts against hyperlipidaemia and oxidative stress in albino Wistar rats with sodium arsenite induced toxicity. World Journal of Pharmacy and Pharmaceutical Sciences, 8 (12): 1-12.

12. Orok, U., Eneji, E., Luke, O., Eyo, R., Sampson, E., Iwara, A. and Oko, O. (2012). Effect of ethanolic root and twig extracts of Gongronema latifolium (Utazi) on kidney function of streptozotocin induced hyperglycemic and normal Wistar rats. Journal of Medicine Sciences, 3 (5): 291- 296.

13. Wybenga, D., Di Glorgio, J. and Pileggi, V. (1971). Manual and automated methods for urea nitrogen measurement in serum. Clinical Chemistry, 17, (9): 891-895.

14. Henry, J. (1974). Clinical diagnosis and management by laboratory method. $16^{\text {th }}$ Edition. Saunders, Philadelphia, 263p.

15. Tietz, N.W. (1996). Fundamentals of Clinical Chemistry.W.B. Saunders. Philadelphia 299p.

16. Young, D. (1997). Effect of drugs on clinical laboratory tests. Annals of Clinical Biochemistry: International Journal of Laboratory Medicine, 34: 579-581.

17. Bancroft, J., stevens, A. and Turner, D. (1996). Theory and practice of histological techniques. $4^{\text {th }}$ Edition, Churchill Livingstone, New York, Edinburgh, London, Melbourne, San Francisco, Tokyo.

18. Hounkpatin , H., Fraser, S., Glidewell, L., Blakeman, T., Lewington, A. and Roderick, $P$ (2019). Predicting risk of recurrent acute kidney injury: A systematic review. Nephron, 21:1-8.

19. Sasaki, A., Oshima, Y. and Fujimura, A. (2007). An approach to elucidate potential mechanism of renal toxicity of arsenic trioxide. Experimental Haematology, 35: 252-262.

20. Yousef, I. El-Demerdash, M. and Radwan, F. (2008). Sodium arsenite induced biochemical perturbations in rats: Ameliorating effect of curcumin. Food and Clinical Toxicology, 48:3506-3511.

21. Connell, D. Yu, Q. and Verma, V. (2016). Influence of exposure time on toxicity: an overview. Toxicology, 355-356, 49-53.

22. Ronco, C. Ferrari, F. and Ricci, Z. (2016). Recovery after acute kidney injury: a new prognostic dimension of the syndrome. American Journal of Respiratory and Critical Care Medicine.195 (6), 711 -714.

23. Nwangwu, C. Josiah, J., Abubakar, E., Ajeighe, O. and Akintola, A. (2011) .Comparative effect of aqueous and ethanolic extracts of Gongronema latifollium on serum kidney and liver biomarkers of normal male rats. Asian Journal of Biological sciences, 4(7):540-547. 